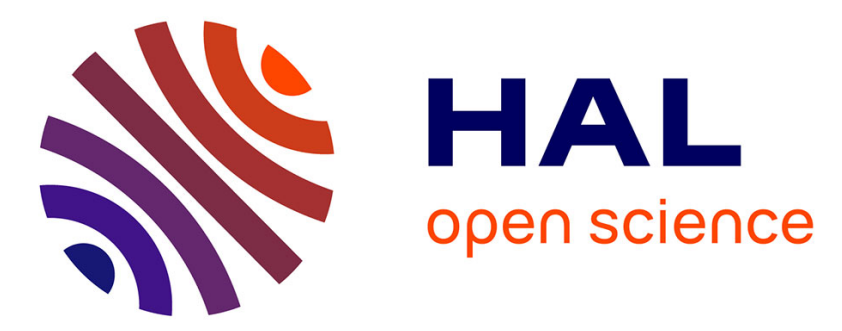

\title{
Bone diagenesis and origin of calcium phosphate nodules from a hominid site in the Lukeino Formation (Tugen Hills, Kenya)
}

Perrine Dericquebourg, Alain Person, Loïc Ségalen, Martin Pickford, Brigitte Senut, Nathalie Fagel

\section{To cite this version:}

Perrine Dericquebourg, Alain Person, Loïc Ségalen, Martin Pickford, Brigitte Senut, et al.. Bone diagenesis and origin of calcium phosphate nodules from a hominid site in the Lukeino Formation (Tugen Hills, Kenya). Palaeogeography, Palaeoclimatology, Palaeoecology, 2019, 536, pp.109377. 10.1016/j.palaeo.2019.109377 . hal-02430608

\section{HAL Id: hal-02430608 https://hal.sorbonne-universite.fr/hal-02430608}

Submitted on 7 Jan 2020

HAL is a multi-disciplinary open access archive for the deposit and dissemination of scientific research documents, whether they are published or not. The documents may come from teaching and research institutions in France or abroad, or from public or private research centers.
L'archive ouverte pluridisciplinaire HAL, est destinée au dépôt et à la diffusion de documents scientifiques de niveau recherche, publiés ou non, émanant des établissements d'enseignement et de recherche français ou étrangers, des laboratoires publics ou privés. 
1 Bone diagenesis and origin of calcium phosphate nodules from a hominid site in the

2 Lukeino Formation (Tugen Hills, Kenya)

3

4 Perrine Dericquebourg (1), Alain Person (2), Loïc Ségalen (2), Martin Pickford (3), Brigitte

$5 \quad$ Senut (3), Nathalie Fagel (1)

6

7 (1) Université de Liège. Laboratoire AGEs (Argile, Géochimie et Environnements 8 sédimentaires), UR Géologie. Quartier Agora. Allée du six Août 14, B-4000 Liège, Belgique.

9 (2) Sorbonne Université, CNRS-INSU, Institut des Sciences de la Terre Paris, ISTeP UMR 107193, F-75005 Paris, France.

11 (3) CR2P UMR 7207 - MNHN, CNRS, Sorbonne Université, Muséum National d'Histoire 12 Naturelle, Département « Origines et évolution », CP 38, 8 rue Buffon, 75231 Paris Cedex 05. 13

14 Corresponding authors: Perrine.Dericquebourg@alumni.uliege.be \& Loïc Ségalen 15 (loic.segalen@sorbonne-universite.fr)

16

17 Highlights:

18 - Calcium phosphate nodules retrieved in the Upper Miocene sedimentary sequence (Lukeino 19 Fm)

20 - The nodules are composed of a francolite matrix with no internal structure.

21 - The diagenesis is related to an advanced degree of bone transformation induced by physical 22 and chemical processes, and possibly bacterial activity.

23 - The process occurred in a relatively dry and confined environment such as a lake edge or 24 marsh. 
Abstract:

The Lukeino Formation (6.09-5.68 Ma; Kenya) is a fossiliferous fluvio-lacustrine sedimentary sequence ( $100 \mathrm{~m}$ thick), which yielded the fossil remains of the oldest East African bipedal hominid, called Orrorin tugenensis. At one of the hominid sites (Aragai), centimetric to pluri-centimetric, indurated calcium phosphate nodules occur in a specific sedimentary layer. Mineralogical and geochemical analyses, coupled with SEM, optical microscopy and cathodoluminescence observations, were performed on four calcium phosphate nodules and one bone showing differential alteration, with characteristics locally similar to that of the nodules, in order to determine the nature and origin of these nodules. A crystallinity index (CI) and histological index (HI) were also assigned to these samples to characterize their degree of transformation. Analyses reveal that all nodules and the studied bone have a similar mineralogical and chemical composition. Nodules show no internal structure and are composed of a carbonate-fluorapatite matrix, including feldspars, clays and spheres of iron and manganese oxides. Their high CI indicates significant recrystallization compared to modern bone. The altered bone shows infilling of the trabecular cavities, characterized by a clay deposit along the walls, oxide spheres with a silica center and carbonate-fluorapatite baguettes. In the highly altered area of the bone, a phenomenon of dissolution and dismantlement of bone structures adjacent to an area characterized by the presence of a phosphate matrix is observed. The genesis of these calcium phosphate nodules seems to result from an advanced stage of transformation of bones, due to a combination of diatoms) and by neoformations of clays and oxides in the bone pores. The bone structure is affected by fracturing and dissolution of carbonate-hydroxylapatite, which reprecipitated in 
51 structures and mineral neoformations were affected by a dismantlement phenomenon, which

52 increased the dissolution of the bone apatite. This resulted in a carbonate-fluorapatite matrix,

53 in which no trace of the initial bone structure is visible. This particular mechanism of genesis

54 of calcium phosphate nodules most probably takes place by action of fluid circulation in a 55 confined environment such as a lake edge or marsh.

56

57 Keywords: Bone structure dissolution, phosphate matrix, carbonate-fluorapatite 58 neoformation, mineralogy, fluvio-lacustrine environment, Upper Miocene, Lukeino 59 Formation.

60 


\section{Introduction}

The Lukeino Formation is a fluvio-lacustrine sedimentary sequence about $100 \mathrm{~m}$ thick, which crops out in the Tugen Hills (Kenya) (Pickford, 1974; Pickford et al., 2009). Radiometric dates (K-Ar) performed on the Kabarnet Trachyte underlying the formation and on the Kaparaina Basalts overlying it indicate an age of $6.09 \pm 0.18(2 \sigma)$ Ma and $5.68 \pm 0.14$ (2б) Ma, respectively (Sawada et al., 2002). Sedimentary deposits associated with Palaeolake Lukeino are mainly silty clay to sandy clay, with a volcanic ash component, and locally include diatomite layers, ferruginous layers, lacustrine phosphorite and carbonate horizons (Dericquebourg et al., 2015; Dericquebourg, 2016).

This sedimentary formation is richly fossiliferous and in particular contains many fossils belonging to large vertebrates (Pickford, 1974; Pickford et al., 2009). The Lukeino Formation is also known to have yielded the remains of the oldest East African bipedal hominid, named Orrorin tugenensis (Senut et al., 2001; Pickford et al., 2002). At Aragai, which is one of the late Miocene sites that yielded hominid remains (Pickford and Senut, 2001; Senut et al., 2018), a specific sedimentary layer contains pluri-centimetric calcium phosphate nodules. These nodules have a different habitus compared to the phosphate horizons previously identified in the Lukeino Formation, and they appear to have a distinct origin. Some fossils sampled at this site also show a particular alteration and have characteristics similar to the nodules.

Geochemical and mineralogical analyses, as well as optical microscopy, scanning electron microscope (SEM) and cathodoluminescence observations, were performed on these nodules and bone fragments. The aim of this study is to characterize the nature of the calcium phosphate nodules and to identify the mechanisms responsible for their genesis, in relation to palaeoenvironmental conditions. 


\section{Geological context}

The upper Miocene sediments of the Lukeino Formation crop out in the Eastern foothills of the Tugen Hills, northwest of Lake Baringo, in the Kenyan part of the East African Rift (Pickford, 1974, 1978) (Fig. 1). The area corresponds to a large tilted block within the rift (Pickford, 1974; Chapman et al., 1978; Hill et al., 1986; Pickford et al., 2009). It is located between the Elgeyo Escarpment, which forms the western flank of the rift and the axial rift depression in which Lake Baringo and Lake Bogoria are located.

This part of the Kenyan Rift has been subjected to intense volcanic and tectonic activity since the early Miocene. The formation of half-grabens has structured the region and led to the uplift of the nascent Tugen Hills during the Middle Miocene, favouring the development of a series of graben lakes (Pickford, 1974; Hill et al., 1986; Williams and Chapman, 1986; Tiercelin et al., 1987; Tiercelin and Lezzar, 2002). Between 7 and 6.1 Ma, volcanic activity was characterized by the eruption of extensive lavas of the Kabarnet Trachyte Formation. At the same time, faults located in the Tugen Hills were reactivated, leading to the creation of a new graben about 6.5 Ma, called the Lukeino Depression in which Palaeolake Lukeino and perilacustrine flats developed. Fluvio-lacustrine deposits $(\sim 100 \mathrm{~m}$ thick), mainly silty-clay to sandy-clay, with diatomites locally, carbonates and phosphate layers (Dericquebourg, 2016) (Fig. 2a), accumulated in this depression from about 6.1 to 5.7 Ma ago. Sediment deposition was interrupted by several volcanic eruptions, leading to the accumulation of ash layers, a basaltic flow (Kapsomin Basalt) and a dolerite sill (Rormuch Sill). The Lukeino Formation was sealed by the Kaparaina Basalts that infilled the depression and obliterated the palaeolake.

Radiometric dates (K-Ar) on the lava flows (measured on groundmass) that bracket the Lukeino Formation, indicate an age between $6.09 \pm 0.14(2 \sigma)$ Ma for the underlying Kabarnet Trachyte, and $5.68 \pm 0.18(2 \sigma)$ Ma for the overlying Kaparaina Basalts at the top of 
111 the series (Sawada et al., 2002). Other studies performed on these lava flows indicated similar

112 ages: between $6.06 \pm 0.13 \mathrm{Ma}(2 \sigma$; sanidine; Hill et al., 1985) and $6.37 \pm 0.05 \mathrm{Ma}(1 \sigma$;

113 anorthoclase; Kingston et al., 2002) for the Kabarnet Trachyte, and between $5.65 \pm 0.13 \mathrm{Ma}$

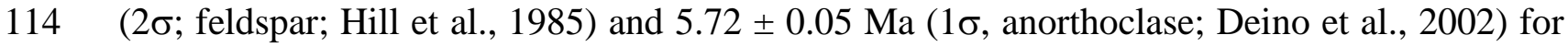
115 the Kaparaina Basalt.

116 The studied material comes from the site of Aragai, located at the southwest end of

117 Palaeolake Lukeino. Sedimentary deposits at this site ( $40 \mathrm{~m}$ thick) overlie the Kabarnet 118 Trachyte and underlie the Rormuch Sill (Fig. 2a). They are located stratigraphically in the

119 lower half of the Lukeino Formation. The sediments are composed of silty-clay alternating 120 with coarser deposits, sandy-clay (Dericquebourg, 2016). The deposits are intercalated with 121 several argillized volcanic ash horizons. Diatomite layers of significant thickness are also 122 observed in the upper half of the sequence. These volcano-sedimentary and biogenic 123 sediments contain unstable components (e.g., volcanic glasses) rich in $\mathrm{Si}, \mathrm{Fe}$ and $\mathrm{Mn}$. These 124 elements will be rapidly released by weathering and hydrothermal alteration (alkaline rift 125 lakes with $\mathrm{pH}$ greater than 10, Tiercelin and Vincens, 1987). They are then transported in 126 solution by the sedimentary pore fluids to matrix surrounding the bones (see Trueman et al., 127 2006). In the alkaline rift lakes, Eh is a reducing agent controlled by the degradation of bone 128 organic matter and $\mathrm{pH} \pm 10$ controlled by the dissolution of biophosphate (Pfretzschner, 129 2004).

131 3. Materials Nineteen samples of powder extracted from four nodules and one altered bone from 133 Aragai were analysed (Table 1). An additional powder sample extracted from a well134 preserved bone from a nearby site (Kapcheberek) was analysed for comparison. Samples were 135 collected in 2004 as part of the Kenya Palaeontology Expedition. 
All nodules came from a single sedimentary horizon (ARG 13) located approximately

$1374.5 \mathrm{~m}$ above the Kabarnet Trachyte (Fig. 2a), at the base of the Aragai sedimentary sequence.

138 This weakly consolidated sedimentary layer with a thickness of about $20 \mathrm{~cm}$ is clayey, red in

139 colour, and includes many pluri-centimetric nodules (Fig. 2b).

140 These highly indurated and massive nodules show neither internal structure nor

141 porosity at the macroscopic scale and present some colour variations (from light grey to red-

142 brown) observed in fresh sections. The choice of powder sampling areas was based on these

143 colour differences to identify any changes in the mineralogical or chemical composition (Fig.

144 2c). Six samples were collected on the largest ( 10 cm in diameter) nodule (labeled NR). It

145 shows some variations in terms of colour (Fig. 2c): the top part of the nodules is bright red

146 (sample NR01) to lighter red (sample NR02); the median part of the nodule is red-brown in

147 colour (sample NR03) with slightly lighter areas (sample NR04); the lower part of the nodule

148 area is the lightest, between light brown-pinkish (sample NR05) and light grey-pink (sample

149 NR06). The NG nodule is smaller ( 4 $\mathrm{cm}$ in diameter) and lighter. The three samples

150 collected correspond to the three colours observed on this nodule (light grey for the sample

151 NG01; pink for NG02; dark grey for NG03) (Fig. 2c). Four samples were taken on the NM

152 nodule with a diameter of $\sim 6 \mathrm{~cm}$ with colours ranging from light grey-pinkish (samples

153 NM01 and NM02) to dark brown (sample NM03). Sample NM04 corresponds to a pinkish

154 area observed on the side (Fig. $2 \mathrm{c})$. The smallest nodule PNR ( $3 \mathrm{~cm}$ in diameter) has a

155 homogeneous bright red internal colour. Two powder samples were collected (PNR01 and

156 PNR02) respectively at the center of the nodule and in the peripheral area (Fig. 2c).

157 In addition, four samples were collected on a relatively large altered bone (OS;

158 lengh: $10 \mathrm{~cm}$; width: $5 \mathrm{~cm}$; thickness: $4 \mathrm{~cm}$ ). This bone likely corresponds to a metaphysis

159 fragment of a long bone belonging to a large unidentified mammal (Fig. 2c). The bone

160 fragment is characterized by a generally well preserved trabecular structure, with some 
161 crystals (length: $\sim 100 / 180 \mu \mathrm{m}$; width: $25 / 30 \mu \mathrm{m}$ ) visible on the walls of cavities in the bone

162 (sample OS01). In the central part of the bone, the trabecular structures are clearly identifiable

163 but a red infilling is locally observed in the cavities of the trabecular bone (sample OS03).

164 The OS02 sample was collected in a red, highly altered area with unidentified bone structures.

165 This bone area shows characteristics similar to the nodules. A last sample (OS04) was

166 collected in the cortical peripheral area (under the former periosteal surface), which seems

167 relatively well preserved.

168 An additional powder sample (KAP07) was extracted from an epiphysis ( $\sim \mathrm{cm}$ in

169 diameter) of long bone belonging to a large unidentified mammal. The bone, showing low

170 taphonomic transformation, is considered to be an unaltered bone and was analysed for

171 comparison with the OS altered bone and nodules. This bone fragment comes from the

172 Kapcheberek site, about $2.5 \mathrm{~km}$ northwest of Aragai, and located stratigraphically in the

173 Kapcheberek Member according to the denomination of Sawada et al. (2002) (Fig. 2a).

174

\section{4. Methods}

176 The four calcium phosphate nodules and the two bone fragments were cut in half

177 through their transverse plane using a diamond water saw. The powder samples $(\mathrm{n}=20$; Fig.

178 2c) were collected on the fresh sections using a rotary drill equipped with a diamond tip.

179 Samples were extracted from different areas to study the variations of mineralogy,

180 crystallinity and chemical composition. All analyses were carried out at the

181 Biomineralizations and Sedimentary Environments Laboratory (BES)-ISTeP of Sorbonne

182 University (Paris), except SEM observations made at the Petrology, Geochemistry, Magmatic

183 Mineralogy Laboratory (PG2M)-ISTeP (Sorbonne University, Paris).

184 All samples were analysed by X-ray diffraction (XRD) using the powder method. The

185 ARG 13 sedimentary horizon (Figure 2) which yielded the nodules was also analysed. 
186 Samples were manually crushed in an agate mortar to obtain a fine (10 microns) powder. The analyses were conducted with a SIEMENS D501 diffractometer. The apparatus is equipped with a $2 \theta$ device and a copper anticathode tube $(30 \mathrm{kv}, 10 \mathrm{~mA})$ to a wavelength of $\lambda \mathrm{CuK} \alpha=$ $1.5418 \AA$. All samples were studied following the same protocol. The acquisition range of the 190 diffractograms is between $3^{\circ}$ and $72^{\circ} 2 \theta$ with a step of $0.02^{\circ} 2 \theta$ and a time per step of $1 \mathrm{~s}$. 191 Interpretations of the diffractograms were performed using the MacDiff software. The semiquantitative estimation of the relative proportions of mineral species was derived from the calculation of the surfaces of the major peak for each mineral identified (Moore and

194 Reynolds, 1997). Subsequently, a crystallinity index (CI) of the apatite was calculated from 195 the XRD diffractogram of all analyzed samples, according to the method of Person et al. 196 (1995)). - The CI corresponds to the sum of peak heights [112] at $2.784 \AA$, [300] at $2.709 \AA$ and [202] at $2.629 \AA$, divided by the height of the major peak [211] at $2.801 \AA$. The CI value increases with the recrystallization degree of the apatite, and ranges generally between $\sim 0$, which corresponds to the carbonate-hydroxylapatite constituting a fresh bone, and $\sim 1$ for the highly recrystallized apatite, associated with a bone showing major taphonomic transformations. The variations on the CI calculations are \pm 0.02 .

Elemental geochemical analyses were performed on four samples from two nodules (NM01, NM03, NM04 and PNR01) and three samples from the OS bone (OS01, OS02, OS04). Sampling was conducted with a rotary drill equipped with a diamond-tipped burr. 50 mg of powder was dried overnight at $80{ }^{\circ} \mathrm{C}$ and weighed into a Teflon beaker before being digested in $5 \mathrm{ml}$ of $30 \%$ nitric acid (Merck, suprapur) and heated at $80{ }^{\circ} \mathrm{C}$ for $1 \mathrm{~h}$. The resulting solution was then diluted with deionized water to a total volume of $50 \mathrm{ml}$, stocked in polypropylene or Teflon tubes and kept for analysis; the standard used for calibration is the NIST SRM1400 “bone ash” following the protocol developed in Maurer et al., (2011). 
The phosphorus percentage was determined by a UV Visible absorption

212 spectrophotometer Spectronic 301 - MILTON ROY; fluorine dosing was carried out using a 213 combined selective electrode of fluoride ions (DC219-F model of METTLER TOLEDO);

214 barium, strontium, iron and manganese contents were determined by ICP-AES with a 215 HORIBA JOBIN YVON JY2000 instrument. Calcium and magnesium were measured with 216 flame atomic absorption spectrophotometer using a HITACHI Z-8100 device. The uncertainty 217 of measurements is $\pm 5 \%$.

218 Observations by optical microscopy were made on polished thin sections from the four 219 nodules (NG, NM, NR and PNR) and the two bones (OS and KAP07) mainly to check the 220 internal organization of nodules and the preservation of bone structures. The preservation of 221 the bone microstructure is represented by the histological index (HI) defined by Hedges et al. 222 (1995) according to the typology of Hackett (1981) to estimate the proportion of intact bone, based on the preservation of some features, such as the Haversian systems, the lamellar structures or osteocytes. The HI ranges between 0 , for a sample having no recognizable structure, and 5, for a very well-preserved sample, almost indistinguishable from fresh bone. A HI was determined for each studied sample to assess the degree of taphonomic transformation. SEM observations were also made on thin sections of the NR and NG nodules and the OS bone, using a ZEISS supra V5 instrument provided with a BRUKER detector in energy dispersive spectroscopy (EDS). Additional observations by optical 230 cathodoluminescence were performed on thin sections from the NR nodule and the OS bone, 231 with an OPEA Catodine instrument. These analyses allow the study of the internal structures, 232 the mineralogical composition of samples and the location of mineral neoformations.

\section{5. Results}

\subsection{X-ray diffraction analyses}


The ARG 13 clay layer containing nodules is composed of $90 \%$ smectite (Fig. $2 \mathrm{~d}$ and

237 Table 1) and of $\sim 5 \%$ quartz and $\sim 5 \%$ sanidine.

All of the nodules have a similar mineralogical composition. They are composed of

70-100\% phosphate (Fig. 2e and Table 1). The phosphate mineral constituting these nodules is carbonate-fluorapatite (francolite), which is confirmed by elemental geochemistry analyses

(Table 2). The other minerals observed are smectite (0-10\%) and sanidine ( 0-20\%). Opal C-

242 T (cristobalite-tridymite) was identified in only one sample from the NG nodule (NG02;

$243 \sim 10 \%$ ) and iron and manganese oxides (goethite and groutite; 5-15\%) were observed in 3

244 samples (NR04; NM02; NM03). Quartz identified in the enclosing clay layer is not observed

245 in the nodules. There is no obvious link between a specific colour zone (redder or greyer

246 zone) in the nodules and a particular mineralogy. The only noticeable change is a stronger

247 occurrence of oxides in the browner areas (Table 1 and Fig. 2). All samples from the nodules

248 have a high crystallinity index (CI), with relatively close values ranging between $\sim 0.7$ and 0.9

249 (Table 1 and Fig. 3). NG and NM nodules have a CI mean value ( 0.76) similar to NR and 250 PNR nodules ( 0.83). -

251 The apatite proportion in the OS bone ranges between $70 \%$ in the highly altered red 252 area (sample OS02) and 100\% in the well preserved cortical area (OS04) (Table 1). The other 253 minerals identified in some areas of bone are smectite (OS02; 10\%), quartz (OS02 and 254 OS03; 10\%), sanidine (OS02; 15\%) and goethite and/or groutite (OS01 and OS03; 10$25525 \%$ ). The crystallinity index is highly variable from one sample to another within this bone, 256 between $\sim 0.6$ and 1.3 (Table 1 and Fig. 3). The lowest CI is associated with the peripheral 257 cortical area (OS04; Fig. 2c). The area showing a red filling with visible bone structures has a 258 very high CI of $\sim 0.9$ (sample OS03). The two highest values of the CI are associated 259 respectively with the well-preserved trabecular area but with crystals observed on the bone 260 walls (OS01; 1) and to the red area, with bone structure highly destructured which is similar 
to the nodules (OS02; 1.3$)$. The high CI are related to a high proportion of recrystallized

262 apatite expressed in trabecular porosity as hexagonal crystals corresponding to two processes:

263 a major dissolution of carbonate-hydroxylapatite and the neoformation of carbonate-

264 fluorapatite. The well-preserved bone KAP07, analysed for comparison, is composed of 100\%

265 apatite and its CI is $\sim 0.4$, substantially lower compared to the other samples (Table 1 and Fig.

$2663)$.

\subsection{Geochemical analyses}

Geochemical analyses were performed on three samples from the NM nodule and one sample from the PNR nodule. The $\mathrm{P}_{2} \mathrm{O}_{5}$ content in the samples ranges between $30 \%$ and $\sim 33 \%$ (Table $2 \mathrm{a}$ ); the percentage of $\mathrm{CaO}$ is $42-46 \%$ and the fluorine content is between $2.5 \%$ and $3 \%$. The $\mathrm{CaO} / \mathrm{P}_{2} \mathrm{O}_{5}$ and $\mathrm{F} / \mathrm{P}_{2} \mathrm{O}_{5}$ ratios are respectively of 1.4 and 0.1 for all samples, and are identical with the values of the carbonate-fluorapatite reference (Table 2c; francolite mineral from Wheal Franco, Devon, England; Palache et al., 1951). Nodules also contain low proportions of $\mathrm{MgO}(0.01-0.03 \%), \mathrm{SrO}(0.5-0.7 \%), \mathrm{BaO}(0.03-0.07 \%)$ and $\mathrm{MnO}(0.3-0.7 \%)$.

The $\mathrm{Fe}_{2} \mathrm{O}_{3}$ values are slightly more scattered than the other elements (Fig. 4), ranging from 2\% (NM01 and PNR01) to 5\% for the NM03 sample. For this last sample, XRD analysis reveals the presence of goethite and/or groutite $(\sim 15 \%$; Table 1$)$ in a dark area from the NM nodule. Moreover the proportions of $\mathrm{Fe}_{2} \mathrm{O}_{3}$ in the samples are high compared to the carbonate-fluorapatite reference.

The contents of $\mathrm{P}_{2} \mathrm{O}_{5}(32-35 \%), \mathrm{CaO}(43-48 \%)$ and $\mathrm{F}(2-3 \%)$ of the three analysed samples from the OS altered bone are relatively constant and in the range of values of results obtained on nodules (Table $2 \mathrm{a}$ and Fig. 4). The $\mathrm{CaO} / \mathrm{P}_{2} \mathrm{O}_{5}(1.3-1.4)$ and $\mathrm{F} / \mathrm{P}_{2} \mathrm{O}_{5}(0.1)$ ratios are also identical to the values obtained on the nodules and indicate that the chemical composition 
of this bone is closer to the carbonate-fluorapatite than to the carbonate-hydroxylapatite

287 (corresponding to the SRM; Table 2b), which constitutes a fresh bone (Table $2 \mathrm{a}$ and $\mathrm{b}$ and

288 Fig. 4). As for the nodules, $\mathrm{BaO}(0.03-0.04 \%), \mathrm{MgO}(0.01-0.02 \%), \mathrm{SrO}(0.3 \%), \mathrm{MnO}(0.2-$

$2890.4 \%$ ) and $\mathrm{Fe}_{2} \mathrm{O}_{3}(1-2 \%)$ are included in relatively constant proportions in the chemical 290 composition of samples from the OS bone.

\subsection{Optical microscopy, SEM and cathodoluminescence observations}

All nodules show the same characteristics in terms of mineralogy and lack of internal analyses indicate that the matrix is comprised of carbonate-fluorapatite, which appears bright yellow (Baele et al., 2011) on the images obtained by cathodoluminescence observations (Fig. 5a). Similar luminescence patterns have been recorded for dentine coming from fossil Gomphotheriidae and Hippopotamidae teeth collected in the Lukeino Formation (Ségalen et al., 2008). This matrix includes a few crystals of K-feldspar (sanidine) (Fig. 5a), as well as clays and many spheres composed of iron and manganese oxides $(\sim 10-30 \mu \mathrm{m}$; Fig. $5 \mathrm{c})$ with a center of silica (identified by EDS analysis). Diatom fragments are also observed by SEM, locally in the NG nodule. They are not clearly identifiable but some preserved characters suggest that they could possibly belong to the genus Aulacoseira. SEM observations locally show an irregular porosity in the apatite matrix, of about $\sim 100-300 \mu \mathrm{m}$ (Fig. 5b). Crystals of carbonate-fluorapatite, as needles, are observed at the transition between these cavities and the apatite matrix (Fig. 5c). No bone structure, as defined by Hedges et al. (1995), was

307 observed in these four nodules. The values of $\mathrm{HI}$ for nodules are therefore equal to 0 (Table 1 308 and Fig. 3).

The analysis of the OS bone reveals significant variability in the preservation of structures. The cortical peripheral area (OSO4) is well-preserved, with a $4<\mathrm{HI}<5$ (Table 1 and 
Fig. 3). The bone structures are also particularly well-preserved in the trabecular area

312 corresponding to sample OS01 $(\mathrm{HI}=4)$. In the areas of samples OS02 and OS03,

313 observations by optical microscopy show that the bone structures (trabecular area) are highly

314 altered to almost non-existent. For these samples, the value of $\mathrm{HI}$ is between 0 and 1.

315 In well-preserved trabecular areas, mineral neoformations were observed in all bone

316 cavities. Fig. 6 shows the succession of these neoformations, which develop inside a studied

317 cavity (Fig. 6a, b and c). A clay deposit is observed along the walls of a cavity in the

318 trabecular bone structure (Fig. 6a and c). Observations by optical microscopy show the

319 presence of oxide spheres (diameter of $\sim 100 \mu \mathrm{m}$ ) in significant quantities inside the cavity

320 (Fig. 6b). SEM observations coupled with EDS analysis confirm the presence of iron and

321 manganese oxides, located above the clay deposits (Fig. 6a). The center of these oxide

322 spheres is composed of silica (Fig. 6a and c). Toward the center of the bone cavity, rectangular-shaped crystals of carbonate-fluorapatite grow above the spheres of oxides and agglomerate together to form an apatite matrix (Fig. 6a and b). These neoformations partially fill the cavities of the trabecular bone structure, reducing the porosity (Fig. 6c). The arrangement of these automorphic crystals of carbonate-fluorapatite in the trabecular structure of bone (Fig. 6d) is revealed by cathodoluminescence observations (bright yellow crystals).

328 Although in this area of the OS bone, the trabecular structures, composed of carbonatehydroxylapatite, are well-preserved, they show local alteration visible by optical microscopy

330 (Fig. 6b; area with a yellow colour). The altered apatite corresponds to darker areas observed

331 by SEM and cathodoluminescence (Fig. 6a and d). SEM observations also indicate the 332 presence, in the cavity of the trabecular bone structure, of a few fragments of unidentifiable diatoms $(\sim 1-10 \mu \mathrm{m})$.

The left upper part of the bone (samples OS02 and OS03, figure 2c) corresponds to a 
infilling, similar to the nodules. SEM observations evidence an unsystematic arrangement of

337 the remaining bone apatite (Fig. 7). Two cavities of the trabecular bone are clearly visible and

338 are partially filled by clay neoformations, oxide and carbonate-fluorapatite automorphic

339 crystals toward the center. However, the trabecular structure surrounding the cavity is

340 fractured and shows significant alteration. Fig. 7 shows that beyond these partially preserved

341 cavities, the bone structures are unidentifiable, only fragments of bone apatite are observed in

342 a matrix. This matrix is composed of francolite, corresponding to carbonate-fluorapatite

343 crystals, which are amalgamated. The matrix also includes some oxide spheres with a centre

344 of silica and clays. The remaining porosity is enclosed by baguettes (automorphic crystals) of

345 francolite and oxide spheres, corresponding to a ghost of the bone cavity. This area

346 corresponds to a transitional phase between well-preserved trabecular structures and the part

347 of the OS bone showing a red infilling with a facies similar to that of the nodules, which

348 illustrates the diagenetic transformation of bones.

349 In comparison, the trabecular bone structures are well-preserved, and no filling of 350 cavities is observed in the KAP07 bone. A histological index of 4 is assigned to this bone 351 (Table 1 and Fig. 3).

\section{Discussion}

\subsection{Characterization of bones and calcium phosphate nodules}

Nodules are composed of a carbonate-fluorapatite matrix including clays, oxides with a centre of silica, and sometimes feldspars or diatom fragments (Fig. 5 and Table 1). They

357 show no internal structure and porosity is almost absent. In bone cavities, neoformations of clays, spheres of oxides with a centre of silica, and carbonate-fluorapatite baguettes develop assemblage. 
All nodules have a similar chemical composition (Table 2), except for an enrichment

in iron linked to the presence of oxides observed locally. The chemical composition of the nodules is similar to the studied altered bone (Table 2 and Fig. 4). However, we note slightly higher $\mathrm{FeO}, \mathrm{MnO}$ and $\mathrm{MgO}$ contents associated with the clays and oxides incorporation in the nodules compared to the bone. Their abundance in the OS bone also increases with the degree of alteration (Fig. 4 and Table 2).

The crystallinity index (CI) of the carbonate-fluorapatite is high for nodules suggesting pervasive recrystallization, and low for the well-preserved parts of the studied bones. The histological index (HI) is 0 for nodules and is relatively high for the wellpreserved bones (Fig. 3). The high values of CI and HI of the OS bone (OSO2 \& OSO3) are 371 caused by the presence of the highly altered areas, which have values similar to the nodules. It 372 is the presence of carbonate-fluorapatite (stable form: insoluble Pasteris and Ding, 2009), 373 which is indistinguishable from carbonate-hydroxylapatite in the calculation of the CI by $374 \mathrm{XRD}$, which causes the high values of CI. The carbonate-fluorapatite (francolite) is 375 neoformed in the nodule. In some fossil bones, the carbonate-fluoroapatite is precipitated 376 from the dissolution of a large part of the bone biomineral (carbonate-hydroxylapatite: bio377 apatite) soluble in the intra-sediment solutions that circulate in the natural porosities of the 378 fossil bones. The carbonate-hydroxylapatite gradually loses its $\mathbf{C O}_{\mathbf{3}}$ radicals and becomes 379 less and less soluble (ie.Trueman et al., 2006; Pan and Darwell , 2010, Aufort et al., 2019). All the analyses performed on these samples therefore indicate that the calcium 381 phosphate nodules from Aragai have characteristics extremely similar to bone showing an 382 advanced degree of diagenesis. The results would also suggest an evolution of the structures 383 and mineral arrangement inside bones culminating in the formation of nodules.

\subsection{Genesis of calcium phosphate nodules}


SEM, optical microscopy and cathodoluminescence observations, performed on 387 nodules and the bone from Aragai, allow the identification of the likely mechanisms 388 responsible for bone alteration leading to the formation of calcium phosphate nodules. The increase in the degree of alteration of bones can be associated with an increase of the crystallinity index (CI) and a decrease of the histological index (HI). The first stages of bones 391 diagenesis (early diagenesis) have been described in many studies (Garland, 1989; Hedges 392 and Millard, 1995; Hedges, 2002; Jans et al., 2002; Trueman et al., 2006; Fernandez-Jalvo et al., 2010; Hinz and Kohn, 2010; Keenan, 2016; Keenan and Engel, 2017). A summary of these processes is shown in Fig. 8. Initially a fresh bone (Fig. 8a), characterized by a HI of 5 (Hedges et al., 1995) and a CI $\sim 0$ (Person et al., 1995), is subjected to microbial activity and collagen degradation (Pfretzschner, 2004; Kendall et al., 2018). The bone structure, particularly the Haversian canals and osteons, are then affected by micro-fracturing mechanisms (Fig. 8b). These stages of early diagenesis take place at $\mathrm{pH}$ of 8-10 (Pfretzschner, 2004) and reveal first in situ apatite recrystallization (Fig. 6-c, b - altered carbonatehydroxylapatite and Fig. 8b). This corresponds to the disappearance of the biological structure on the edge of the bone fragments whose anatomic shapes are still preserved.

The subsequent stages of bone transformation, , are characterized by the precipitation 403 of minerals in the bone cavities and the alteration of the bone structure. The mineral neoformations observed along the walls of trabecular cavities (Fig. 6) suggest that in the bone pores the clays accumulate first, together with components present in the environment, such as detrital feldspars or diatoms (Fig. 8c).

Neoformation of iron and manganese oxide spheres, with a centre of silica, corresponds to a second generation of minerals, which accumulate contiguously along the trabecular walls, on top of the clays (Fig. 6 and 8d). The silica in solution originates from the dissolution of diatoms and silica mobility in the trabecular cavities involves $\mathrm{pH}$ conditions 
higher than 9 (Iler, 1979). The formation of spheres requires a reduction in $\mathrm{pH}$. The Fe and

412 Mn mobility requires suboxic condiditons. Meanwhile, the fracturing of bone structures 413 continues and intensifies (due to the taphonomic processes and internal neoformations); the 414 carbonate-hydroxylapatite constituting the bone structures begins to dissolve (Fig. 6 and 8d).

415 Microscope observations reveal the presence of carbonate-fluorapatite automorphic crystals 416 inside the trabecular cavities. They seem to develop on top of clays and oxides spheres along 417 the walls (Fig. 6 and 8e). It is likely that the bone undergoes a process of dissolution of 418 carbonate-hydroxylapatite, which recrystallizes in situ in the form of carbonate-fluorapatite 419 automorphic crystals. However, this requires that fluoride is available in sufficient quantities 420 in the environment. Hydrothermal springs, the presence of which is recorded at some sites in 421 the Lukeino Formation (Pickford et al., 2009) could supply fluorine. This hypothesis is 422 discussed in the case of deposition of lacustrine phosphorite horizons in Dericquebourg et al. (2015).

Observations on the OS bone clearly show that the bone structures, as well as mineral neoformations in the cavities, are then affected by a diagenetic process (Fig. 7). The 426 phenomena of dissolution-reprecipitation of bone apatite increased and are associated with an 427 increase of fracturing of the trabecular structures (Fig. 8f). Carbonate-fluorapatite automorphic crystals develop inside fractures and cavities, where they amalgamate to fill them almost completely, and form a phosphate matrix (Fig. 7 and 8g). Fig. 7 illustrates the 430 dismantlement phenomenon of bones, characterized by a dispersion of the altered bone 431 fragments, clays and oxides, coupled with the formation of the carbonate-fluorapatite matrix, 432 which includes these components (Fig. 8h). This causes a gradual decrease of the porosity and 433 the disappearance of identifiable bone structures (Fig. 7 and 8i), and leads to the formation of 434 calcium phosphate nodules. Composed of a carbonate-fluorapatite matrix including oxides, 435 clays and locally feldspars (Fig. 5 and 8j), they are therefore characterized by the absence of 
436 internal structure, with a $\mathrm{HI}$ equal to 0 (Fig. 3 and 5) and a high CI (Fig. 3) indicating a

437 significant degree of transformation.

438 Mineralogical analyses of this clay layer (Fig. 2 and Table 1) and sedimentary context 439 suggest a relatively poorly drained environment (Dericquebourg, 2016). The integration of 440 diatom fragments and detrital particles from the environment (feldspar and clay) as well as the 441 dismantlement processes of bone structures require fluid circulation. However, the dissolution 442 of bone apatite and the carbonate-fluorapatite precipitation in situ in the bone cavities indicate 443 a relatively confined environment. This suggests that these processes of bone diagenesis and 444 genesis of these single calcium phosphate nodules probably took place in a lake edge or 445 marshy environment.

\section{Conclusion}

The aim of this study was to characterize calcium phosphate nodules observed in a specific sediment layer of the Aragai sedimentary sequence, located at the base of the Lukeino Formation, and to determine their genesis. The mineralogical and geochemical analyses, coupled with observations by optical microscopy, SEM and cathodoluminescence, of four nodules and one bone, which shows differential alteration, highlighted several points:

1) Nodules are composed of a carbonate-fluorapatite matrix, including clays, feldspars, spheres of oxides with a centre of silica, and locally rare fragments of diatoms. They show no internal structure.

2) In the trabecular area of the studied bone, mineral neoformations of clays, oxide spheres with a centre of silica and carbonate-fluorapatite automorphic crystals develop inside cavities, filling them up. The most altered part of the bone shows characteristics similar to the nodules, with disappearance of osseous structures and formation of a carbonate-fluorapatite matrix. 
3) The formation of nodules is related to mineral neoformations in the bone cavities and dissolution of carbonate-hydroxylapatite constituting the bone structures, which precipitates in situ in the form of carbonate-fluorapatite. These processes are coupled with a dismantlement phenomenon leading to the formation of an apatite matrix with extremely low porosity, and including the mineral neoformations.

4) The mineralogy of the sediment layer containing these calcium phosphate nodules indicates that the dismantlement processes, as well as the integration of diatoms, require fluid circulation and the in situ recrystallization suggests a confined environment taking place in a lake edge or marshy environment.

The genesis of the calcium phosphate nodules which occur at the base of the Lukeino

Formation, is related to an advanced degree of bone transformation in a confined environment

with suboxic phases and basic $\mathrm{pH}$ (similar to the modern lakes and hydrothermal circulations observed in the Gregory rift) which led to mobility of $\mathrm{Fe}$, Mn elements and $\mathrm{SiO}_{2}$, respectively.

\section{Acknowledgements}

476 Authorization to carry out research in the Tugen Hills was provided by the Government of 477 Kenya (The Ministry of Research and Technology, at the time the Ministry of Higher 478 Education, Science and Technology). Local affiliation is with the Orrorin Community 479 Organisation. The field work was financed by the CNRS (GDRI 193, UMR 7207), the French 480 Ministry of Foreign Affairs (Advisory Commission on Archaeological Research Abroad). The 481 authors acknowledge Egerton University (Kenya), as well as the colleagues of the Kenya 482 Palaeontology Expedition for their input on the field. We wish greatly to thank Omar 483 Boudouma (ISTeP-Sorbonne Université) for the acquisition of SEM images; Marylène 484 Person, Nathalie Labourdette and Jamel Benmamar (ISTeP-Sorbonne Université) for their 485 help regarding respectively geochemical and XRD analyses; Frédéric Delbès (ISTeP- 
Sorbonne Université) for producing the thin sections. Lastly we also acknowledge the three anonymous reviewers for their useful comments.

\section{References}

Aufort, J., Gervais, C., Ségalen, L., Labourdette, N., Coelho-Diogo, C., Baptiste, B., Beyssac, O., Amiot, R., Lécuyer, C., Balan, E., 2019. Atomic scale transformation of bone in controlled aqueous alteration experiments, Palaeogeography, Palaeoclimatology, Palaeoecology 526, 80-95.

Baele, J.-M., Papier, S., Barriquand, L., Barriquand J., 2011. Insights into the use of cathodoluminescence for bone taphonomy of fossil Ursidae from the Azé Cave, Saône-et Loire, France. Quaternaire, Hors-série 4, 291-296.

Chapman, G.R., Lippard, S.J., Martyn, J.E., 1978. The stratigraphy and structure of the Kamasia Range, Kenya Rift Valley. Journal of the Geological Society of London 135, 265-281.

Deino, A.L., Tauxe, L., Monaghan, M., Hill, A., 2002. ${ }^{40} \mathrm{Ar} /{ }^{39} \mathrm{Ar}$ geochronology and paleomagnetic stratigraphy of the Lukeino and lower Chemeron Formations at Tabarin and Kapcheberek, Tugen Hills, Kenya. Journal of Human Evolution 42, 117-140.

Dericquebourg, P., Person, A., Ségalen, L., Pickford, M., Senut, B., Fagel, N., 2015. Environmental significance of Upper Miocene phosphorites at hominid sites in the Lukeino Formation (Tugen Hills, Kenya). Sedimentary Geology 327, 43-54.

Dericquebourg, P., 2016. Les dépôts sédimentaires de la Formation de Lukeino, enregistreurs des fluctuations environnementales, associées aux premiers hominidés est-africains (Collines Tugen, Rift Gregory, Kenya), PhD Thesis, http://hdl.handle.net/2268/201893 Liège University. 
Fernandez-Jalvo, Y., Andrews, P., Pesquero, D., Smith, C., Marin-Monfort, D., Sanchez, B.,

Geigl, E.-M., Alonso, A., 2010. Early bone diagenesis in temperate environments. Part I: Surface features and histology. Palaeogeography, Palaeoclimatology, Palaeoecology 288, 62-81.

Garland, A.N., 1989. Microscopical analysis of fossil bone. Applied Geochemistry 4, 215229.

Hacket, C.J., 1981. Microscopical focal destructions (tunnels) in exhumed human bone. Medicine, Science, and the Law 21, 243-265.

Hedges, R.E.M., 2002. Bone diagenesis: an overview of processes. Archaeometry 44, 319328.

Hedges, R.E.M., Millard, A.R., 1995. Bones and Groundwater: Towards the Modelling of Diagenetic Processes. Journal of Archaeological Science 22, 155-164.

Hedges, R.E.M., Millard, A.R., Pike, A.W.G., 1995. Measurements and relationships of diagenetic alteration of bone from three archaeological sites. Journal of Archaeological Science 22, 201-209.

Hill, A., Drake, R., Tauxe, L., Monaghan, M., Barry, J.C., Behrensmeyer, A.K., Curtis, G., Jacobs, B.F., Jacobs, L.L., Johnson, N., Pilbeam, D., 1985. Neogene palaeontology and geochronology of the Baringo Basin, Kenya. Journal of Human Evolution 14, 759 -773.

Hill, A., Curtis, G., Drake, R., 1986. Sedimentary stratigraphy of the Tugen Hills, Baringo, Kenya. In: Frostick, L.E., Renaut, R.W., Reid, I., Tiercelin, J.-J. (Eds.), Sedimentation in the African Rifts. Geological Society of London Special Publication 25, pp. 285-295.

Hinz, E.A., Kohn, M.J., 2010. The effect of tissue structure and soil chemistry on trace element uptake in fossils. Geochimica et Cosmochimica Acta 74, 3213-3231.

Iler, R.K., 1979. The Chemistry of Silica: Solubility, Polymerization, Colloid and Surface Properties and Biochemistry of Silica. Wiley (ed). 896p. 
Jans, M. M. E., Kars, H., Nielsen-Marsh, C. M., Smith, C. I., Nord, A. G., Arthur, P., \& Earl, N., 2002. In situ preservation of archaeological bone. A histological study within a multidisciplinary approach. Archaeometry 44, 343-352.

Keenan, S.W., 2016. From bone to fossil: a review of the diagenesis of bioapatite. American Mineralogist 101, 1943-1951.

Keenan, S.W., Summers Engel, A., 2017. Early diagenesis and recrystallization of bone. Geochimica et Cosmochimica Acta 196, 209-223.

Kendall, C., Høier Eriksen, A.-M., Kontopoulos, I., Collins, M.J., Turner-Walker, G., 2018. Diagenesis of archeological bone and tooth. Palaeogeography, Palaeoclimatology, Palaeoecology 491, 21-37.

Kingston, J.D., Jacobs, B.F., Hill, A., Deino, A., 2002. Stratigraphy, age and environments of the late Miocene Mpesida Beds, Tugen Hills, Kenya. Journal of Human Evolution 42, 95116.

Maurer, A.-F., Gerard, M., Person, A., Barrientos, I., del Carmen Ruiz, P., Darras, V., Durlet, C., Zeitoun, V., Renard, M., Faugère, B., 2011. Intra-skeletal variability in trace elemental content of Precolumbian Chupicuaro human bones: the record of post-mortem alteration and a tool for palaeodietary reconstruction. Journal of Archaeological Science $38,1784-1797$.

Moore, D.M., Reynolds, R.C., 1997. X-Ray Diffraction and the Identification and Analysis of Clay Minerals (Second Edition). Oxford University Press, Oxford, 378pp.

Palache, C., Berman, H., Frondel, C., 1951. Dana’s System of Mineralogy (Seventh Edition). John Wiley and Sons, INC, New York, 1124pp.

Pan, H., Darwell, B.W., 2010. Effect of carbonate on hydroxyapatite solubility. Crystal Growth \& Design10, 845-850. 
Pasteris J.D., Ying D.Y., 2009. Experimental fluoridation of nanocrystalline apatite. American Mineralogist 94, 53-63.

Person, A., Bocherens, H., Saliège, J.-F., Paris, F., Zeitoun, V., Gérard, M., 1995. Early diagenetic evolution of bone phosphate: An X-ray diffractometry analysis. Journal of Archaeological Science 22, 211-221.

Pfretzschner, H.-U., 2004. Fossilization of Haversian bone in aquatic environments. Comptes Rendus Palevol 3, 605-616.

Pickford, M., 1974. Stratigraphy and Palaeoecology of five late Cainozoic formations in the Kenya Rift Valley. University of London (Unpublished PhD Thesis).

Pickford, M., 1978. Stratigraphy and mammalian palaeontology of the late-Miocene Lukeino Formation, Kenya. In: Bishop, W.W. (Ed.), Geological Background to Fossil Man.

Pickford, M., Senut, B., 2001. The geological and faunal context of Late Miocene hominid remains from Lukeino, Kenya. Comptes Rendus de l'Académie des Sciences de ParisSeries IIA, Earth and Planetary Sciences 332, 145-152.

Pickford, M., Senut, B., Gommery, D., Treil, J., 2002. Bipedalism in Orrorin tugenensis revealed by its femora. Comptes Rendus Palevol 1, 191-203.

Pickford, M., Senut, B., Cheboi, K., 2009. The Geology and Palaeobiology of the Tugen Hills, Kenya: Rift Tectonics, Basin Formation, Volcanics and Sedimentation. Geo-Pal Kenya 1, 4-133.

Pucéat,E., Reynard, B., Lécuyer, C., 2004. Can crystallinity be used to determine the degree of chemical alteration of biogenic apatites? Chemical Geology 205, 83-97.

Sawada, Y., Pickford, M., Senut, B., Itaya, T., Hyodo, M., Miura, T., Kashine, C., Chujo, T., Fujii, H., 2002. The age of Orrorin tugenensis, an early hominid from the Tugen Hills, Kenya. Comptes Rendus Palevol 1, 293-303. 
Ségalen L., Rafélis (de) M., Lee-Thorp J.A., Maurer A-F., Renard M., 2008. Cathodoluminescence tools provide clues to depositional history in Miocene and Pliocene teeth, Special issue "V International Bone Diagenesis Meeting". Palaeogeography, Palaeoclimatology, Palaeoecology 266, 246-253.

Senut, B., Pickford, M., Gommery, D., Mein, P., Cheboi, K., Coppens, Y., 2001. First hominid from the Miocene (Lukeino Formation, Kenya). Comptes Rendus de l'Académie des Sciences de Paris-Series IIA, Earth and Planetary Sciences 332, 137-144.

Senut B, Pickford M, Gommery D., 2018. Dental anatomy of the early hominid, Orrorin tugenensis, from the Lukeino Formation, Tugen Hills, Kenya. Revue de Paléobiologie 37, 577-591. DOI: 10.5281/zenodo.2545075.

Tiercelin, J.-J., Lezzar, K.-E., 2002. A 300 million years history of rift lakes in Central and East Africa: an updated broad review. In: Odada, E.O., Olago, D.O. (Eds.), The East African Great Lakes: Limnology, Paleolimnology and Biodiversity. Advances in Global Change Research 12, pp. 3 - 60.

Tiercelin, J.J., Vincens, A., 1987. Le Demi-graben de Baringo-Bogoria, Rift Gregory, Kenya. Bulletin du Centre de Recherche et d'Exploration 11. Elf Aquitaine Production, Pau, France, pp. 249-540.

Trueman, C.N., Behrensmeyer, A.K., Potts, R., Tuross, N., 2006. High-resolution records of 602 location and stratigraphic provenance from the rare earth element composition of fossil bones. Geochimica et Cosmochimica Acta 70, 4343-4355.

Williams, L.A.J., Chapman, G.R., 1986. Relationships between major structures, salic volcanism and sedimentation in the Kenya Rift from the equator northwards to Lake Turkana. In: Frostick, L.E., Renaut, R.W., Reid, I., Tiercelin, J.-J. (Eds.), Sedimentation in the African Rifts. Geological Society of London Special Publication 25, pp. 59-74. 
612 Table 1. Mineralogical composition of nodules, bones and enclosing clay layer (in \%, 613 uncertainty $\pm 5 \%$ ); crystallinity index (CI) of the apatite calculated from XRD diffractograms 614 (without units, uncertainly \pm 0.02 ); and histological index (HI) associated, determined by 615 optical observations (without unit). See Fig. 2 for the location of samples.

616

617 Table 2. Chemical composition of nodules and the OS bone. See Fig. 2 for the location of 618 samples. a) Geochemical analyses of some samples from calcium phosphate nodules and 619 bone. b) SRM values used for geochemical analyses (bone ash: hydroxylapatite). In this 620 study SRM is also used on reference fresh bone for comparison with the studied bone 621 and nodules. c) For comparison, chemical composition of: Reference carbonate-fluorapatite 622 (francolite), specimen from Wheal Franco, Devon, England (Palache et al., 1951) and 623 Reference carbonate-hydroxylapatite, specimen from the Kaiserstuhl, Germany (Palache et 624 al., 1951). All values are in weight \%. na: not analysed. ${ }^{(1)}$ Calculated in this paper from the 625 bibliographic data.

626 
Figure 1. Location map of the studied site (Aragai) within the Lukeino Formation (Tugen

630 Hills, northwest of Lake Baringo, Kenya). The fault network represented on the map is after 631 Pickford and Senut (2001).

632

633 Figure 2. Sedimentological data, materials studied and mineralogy of nodules and the enclosing clayey layer. (a) Synthetic lithological columns of the Lukeino Formation and the Aragai sedimentary sequence (Dericquebourg, 2016). The brown lines and the dotted line indicate the respective stratigraphic positions of the Aragai sedimentary sequence and the ARG 13 sedimentary layer containing nodules, on the lithological column of the Lukeino Formation. The stratigraphy and ages are after Sawada et al. (2002). (b) Field photo showing the nodules in situ within the ARG 13 sediment layer. (c) Studied material and location of different samples extracted from the four nodules (NR, NG, NM, PNR) and the altered bone (OS). (d) XRD diffractogram of the enclosing clay layer (ARG 13) and pie chart showing the

642 mineralogical composition. S - smectite; F - K-feldspar (sanidine); Q - quartz. (e) XRD 643 diffractogram of the NR06 sample extracted from the NR nodule and pie chart showing the mineralogical composition, which reflects the mean mineralogy of different studied nodules. S - smectite; F - K-feldspar (sanidine); A - apatite (carbonate-fluorapatite).

647 Figure 3. Evolution of the crystallinity index (CI) and histological index (HI) between the 648 studied nodules and bones. CI values lower than 1 corresponding to recrystallized carbonate649 hydroxylapatite and CI value higher than 1 corresponding to neoformed carbonate650 fluorapatite. The location of the samples is provided in Fig. 2. 
652 Figure 4. Ternary diagram showing similarities in chemical composition between the calcium 653 phosphate nodules and the OS altered bone. Values of NIST SRM 1400 (bone ash: 654 hydroxylapatite) are indicated for comparison (black star).

655

656 Figure 5. Mineralogy and internal structure of nodules. (a) Cathodoluminescence observation 657 (NR nodule). Nodules are composed of a micritic matrix of carbonate-fluorapatite in bright 658 yellow including feldspar (sanidine). (b) SEM image (NR nodule) showing pores in the 659 phosphate matrix, observed only at the microscopic scale. (c) Optical microscope observation 660 (NR nodule). The matrix of apatite contains numerous spheres of oxide (goethite and 661 groutite); crystals in the form of needles are observed at the transition matrix - cavities.

662

663 Figure 6. Mineral neoformations inside bone cavities (OS bone). (a) SEM image (back664 scattered electrons) showing the infilling of a cavity of the trabecular bone structure. (b) 665 Optical microscope observation of the same cavity of the trabecular bone structure. (c) 666 Interpretive drawing of this cavity of the trabecular bone structure. (d) Cathodoluminescence 667 observation at a larger scale. The neoformation of carbonate-fluorapatite is in bright yellow. a 668 - carbonate-hydroxylapatite, b - altered carbonate-hydroxylapatite, c - clay, d - Fe and Mn 669 oxides, e - silica, f - carbonate-fluorapatite, $\mathrm{g}$ - bone porosity.

670

671 Figure 7. Transformation of bone structures with processes of dissolution-recrystallisation 672 and precipitation leading to the formation of the calcium phosphate matrix observed in the OS 673 bone. (a) SEM image (back-scattered electrons). (b) Interpretive drawing: a - carbonate674 hydroxylapatite, b - altered carbonate-hydroxylapatite, c - clay, d - Fe and Mn oxides, e 675 silica, f - carbonate-fluorapatite, $\mathrm{g}$ - bone pores.

676 
677 Figure 8. Conceptual synthesis of processes responsible for the genesis of calcium phosphate 678 nodules from the transformation and dissolution of bone structures. Optical microscope 679 photos were made on the KAP 07 relatively fresh bone (photos A and B), the OS altered bone 680 (photos C to I) and the NM nodule (photo J). Legend of drawings as in Fig. 7. The blue 681 mineral corresponds to $\mathrm{K}$-feldspar (sanidine). $\mathrm{IH}$ : histological index. * according to 682 Pfretzschner (2004).

683 
Table 1

\begin{tabular}{|c|c|c|c|c|c|c|c|c|c|}
\hline Sample & & Smectite \% & Quartz \% & Sanidine \% & Opal CT \% & Gr-Go \% & Apatite \% & $\mathrm{Cl}$ & $\mathrm{HI}$ \\
\hline \multicolumn{10}{|l|}{ Clay layer } \\
\hline ARG 13 & & 90 & 4 & 6 & - & - & - & - & - \\
\hline \multicolumn{10}{|l|}{ Nodules } \\
\hline NR01 & & 3 & - & 5 & - & - & 93 & 0.84 & 0 \\
\hline NR02 & & 3 & - & - & - & - & 97 & 0.86 & 0 \\
\hline NR03 & & - & - & - & - & - & 100 & 0.85 & 0 \\
\hline NR04 & & - & - & 5 & - & 9 & 87 & 0.87 & 0 \\
\hline NR05 & & - & - & 8 & - & - & 92 & 0.77 & 0 \\
\hline NR06 & & 2 & - & 10 & - & - & 88 & 0.81 & 0 \\
\hline NG01 & & 3 & - & 8 & - & - & 89 & 0.72 & 0 \\
\hline NG02 & & 2 & - & 13 & 12 & - & 73 & 0.82 & 0 \\
\hline NG03 & & 4 & - & 10 & - & - & 86 & 0.77 & 0 \\
\hline NM01 & & 3 & - & 13 & - & - & 84 & 0.71 & 0 \\
\hline NM02 & & 7 & - & 12 & - & 8 & 74 & 0.77 & 0 \\
\hline NM03 & & 5 & - & 11 & - & 14 & 70 & 0.83 & 0 \\
\hline NM04 & & 4 & - & 14 & - & - & 82 & 0.76 & 0 \\
\hline PNR01 & & 4 & - & 22 & - & - & 74 & 0.81 & 0 \\
\hline PNR02 & & 7 & - & 16 & - & - & 77 & 0.88 & 0 \\
\hline Mean & & 3 & - & 10 & - & - & 84 & 0.80 & 0 \\
\hline \multirow{2}{*}{ Variation } & Min. & 0 & - & 0 & 0 & 0 & 70 & 0.71 & 0 \\
\hline & Max. & 7 & - & 22 & 12 & 14 & 100 & 0.88 & 0 \\
\hline \multicolumn{10}{|l|}{ Bones } \\
\hline OS01 & & - & - & - & - & 23 & 77 & 1.03 & 4 \\
\hline OS02 & & 7 & 10 & 13 & - & - & 70 & 1.27 & $0<\mathrm{HI}<1$ \\
\hline OS03 & & - & 10 & - & - & 10 & 80 & 0.92 & $0<\mathrm{HI}<1$ \\
\hline OS04 & & - & - & - & - & - & 100 & 0.62 & $4<\mathrm{HI}<5$ \\
\hline KAP07 & & - & - & - & - & - & 100 & 0.41 & 4 \\
\hline \multirow{2}{*}{ Variation } & Min. & 0 & 0 & 0 & - & 0 & 70 & 0.41 & $0<H \mid<1$ \\
\hline & Max. & 7 & 10 & 13 & - & 23 & 100 & 1.27 & $4<\mathrm{HI}<5$ \\
\hline
\end{tabular}

685

686 
Table 2

688

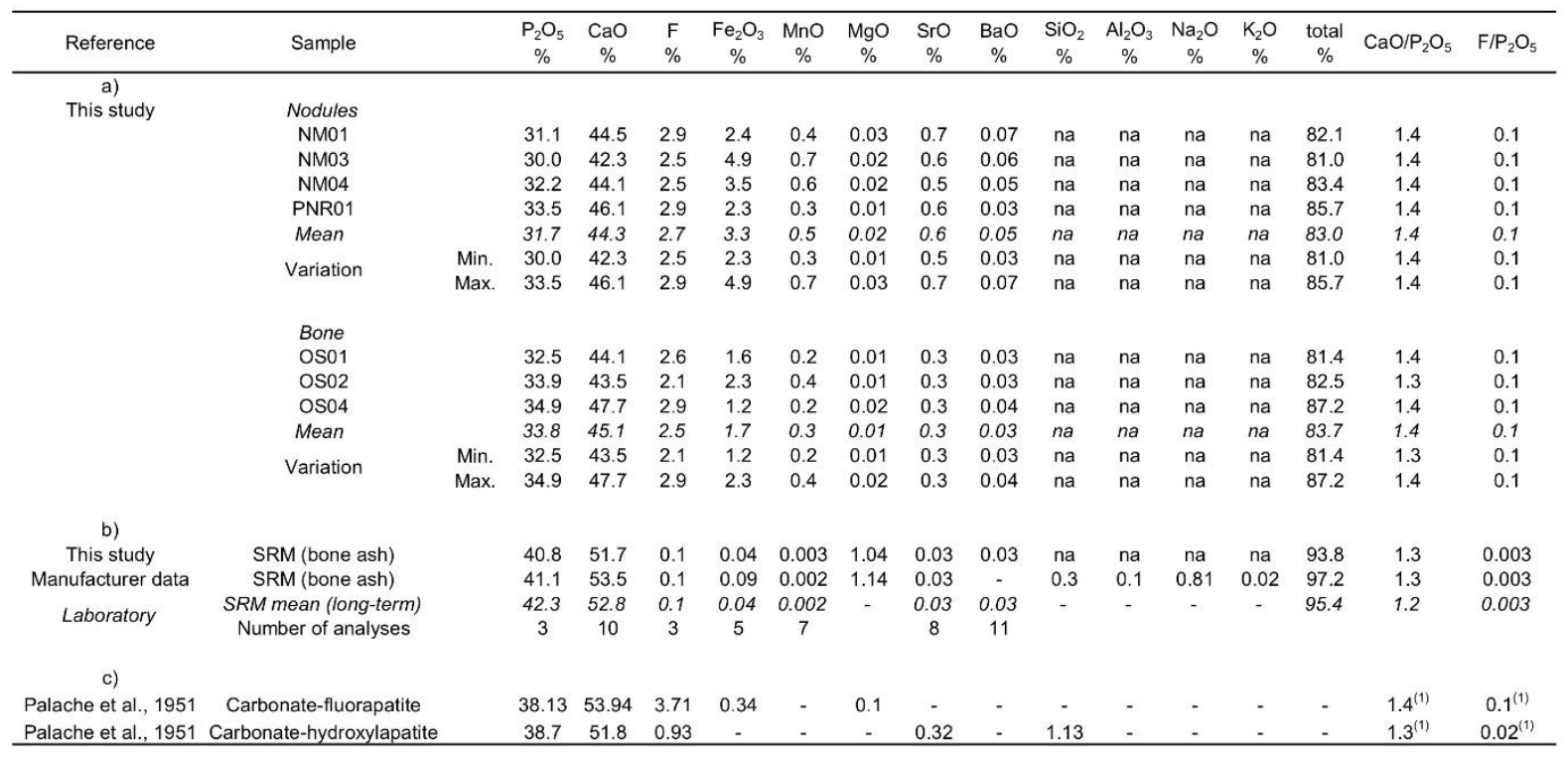


690

691

692

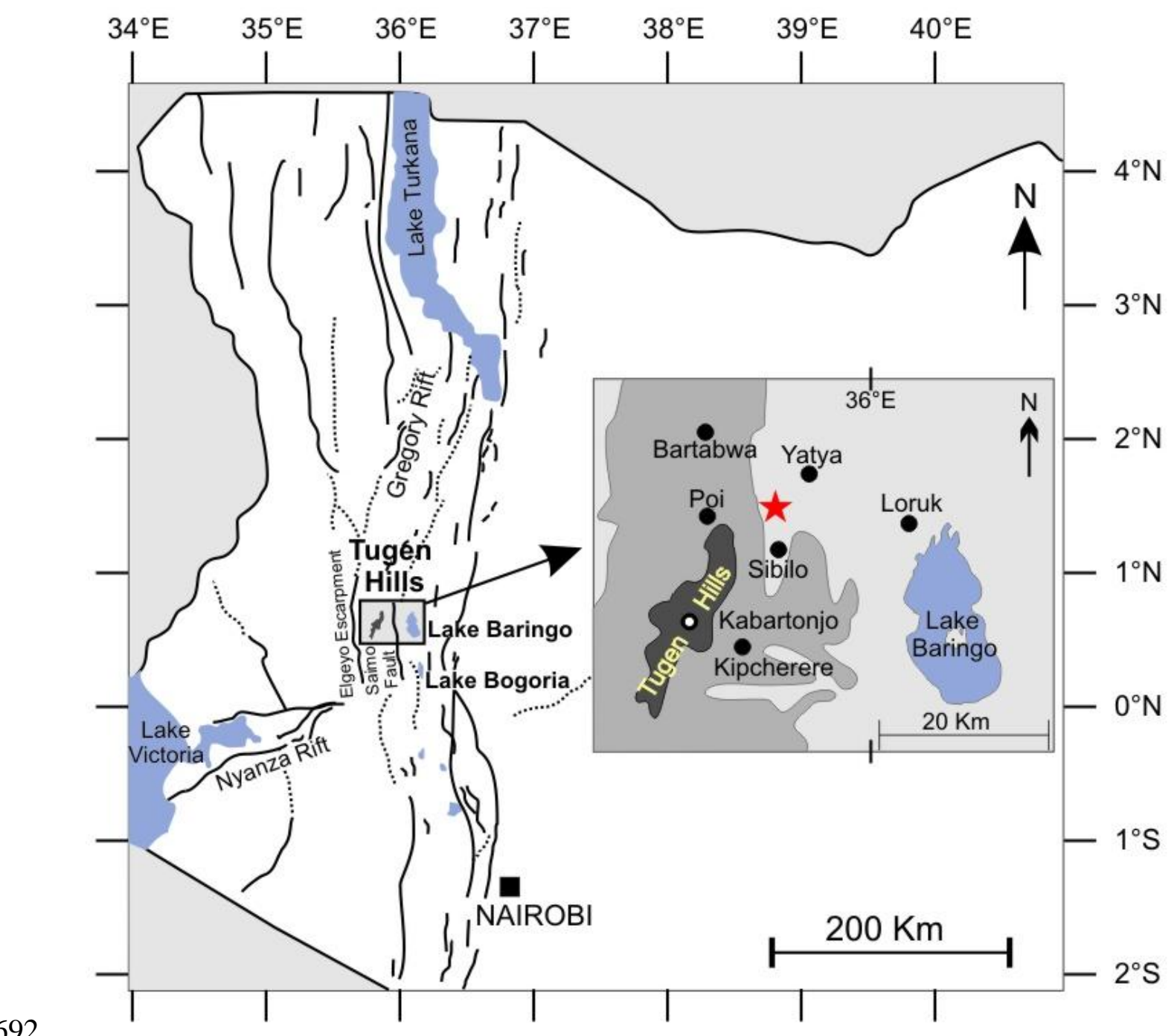

Figure 1

693 
694 Figure 2

695

696

697

698

699

700

701

702

703

704

705

Page 33 sur 40 

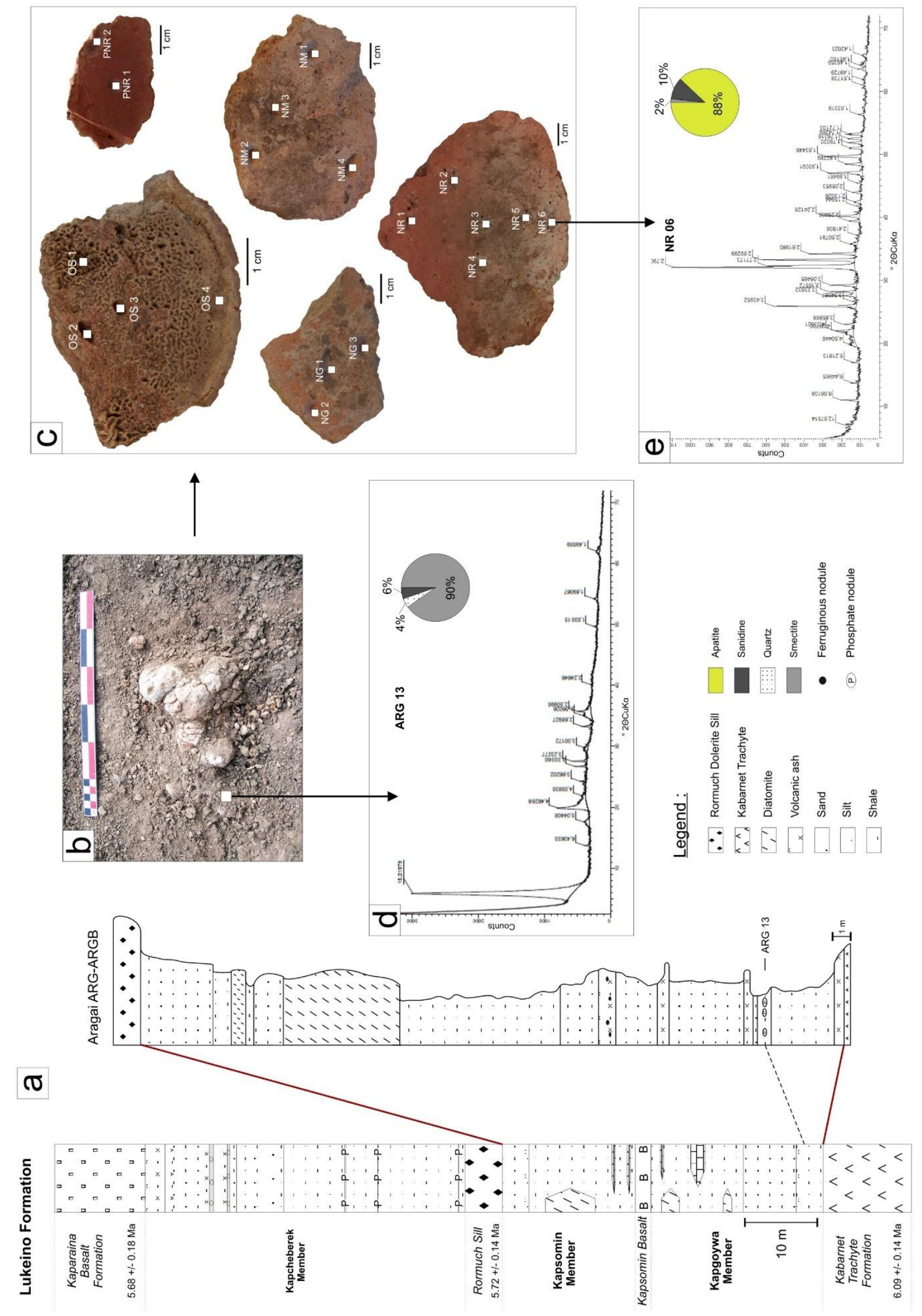
$707 \quad$ Figure 3

708

709

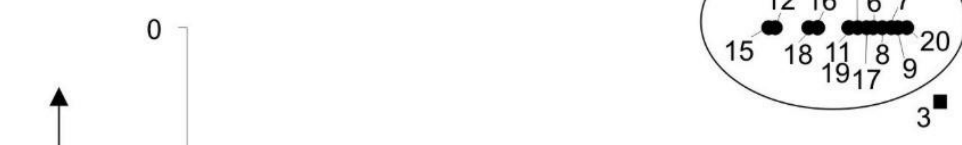

710

well preserved bones

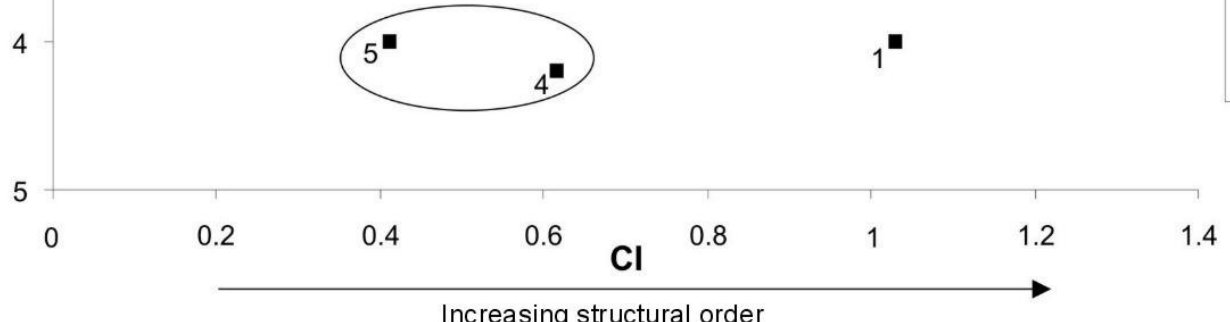

20 PNR02

19 PNR01

$17 \mathrm{NMO4}$

$16 \mathrm{NMO} 2$

$15 \mathrm{NM01}$

$13 \mathrm{NGO2}$

$12 \mathrm{NG} 1$

11 NR06

1)

$9 \mathrm{NRO4}$

$8 \mathrm{NRO3}$

7 NR02

$\begin{array}{ll}6 & \text { NR01 } \\ 5 & \text { KAP07 }\end{array}$

4 OS04

3 OS03

2 OS02

1 OS01

- Nodule

- Bone

Increasing structural order

711

712

Page 35 sur 40 
713 Figure 4

714

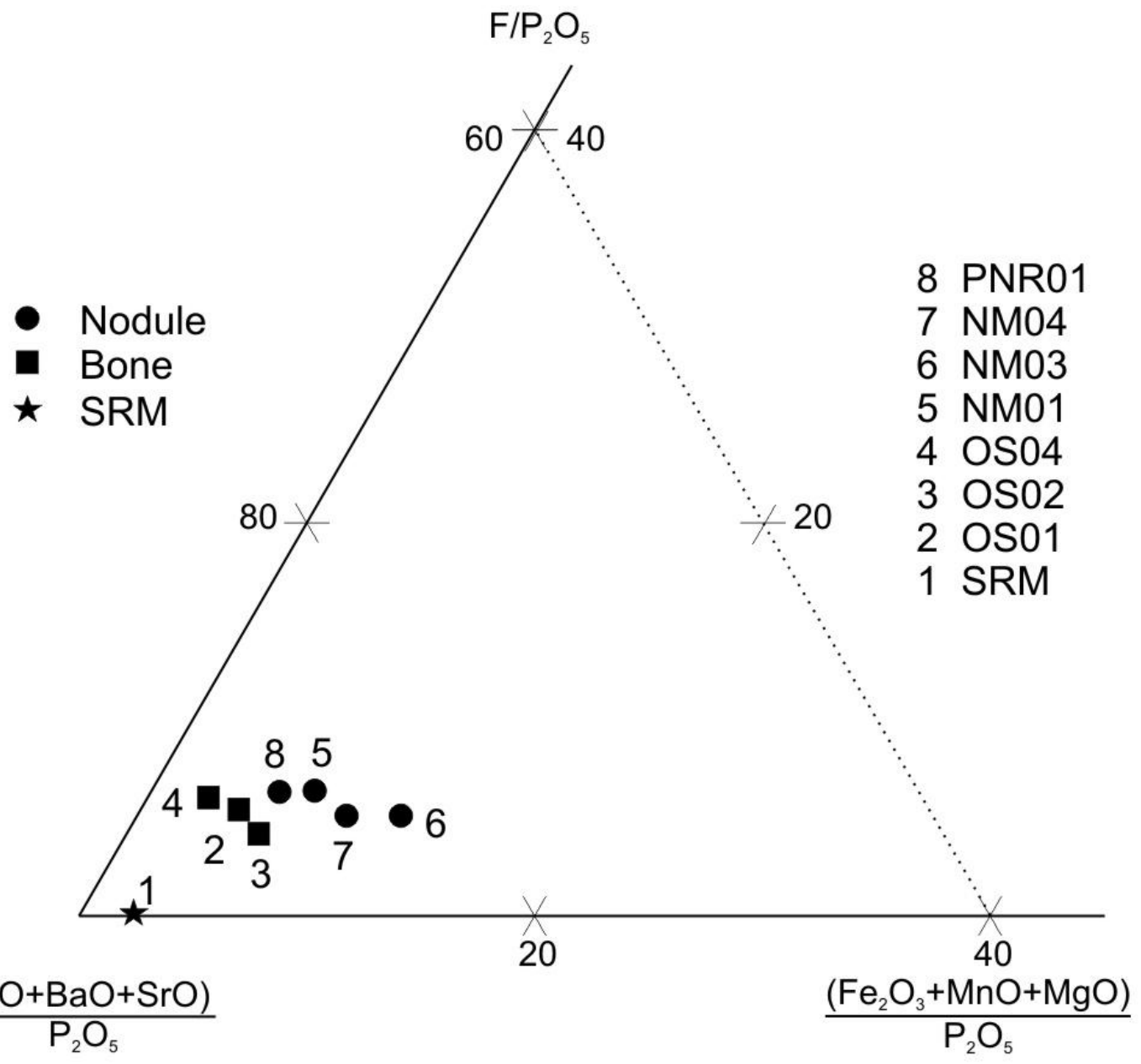

715

$\frac{(\mathrm{CaO}+\mathrm{BaO}+\mathrm{SrO})}{\mathrm{P}_{2} \mathrm{O}_{5}}$ 


\section{Figure 5}

\section{7}

718
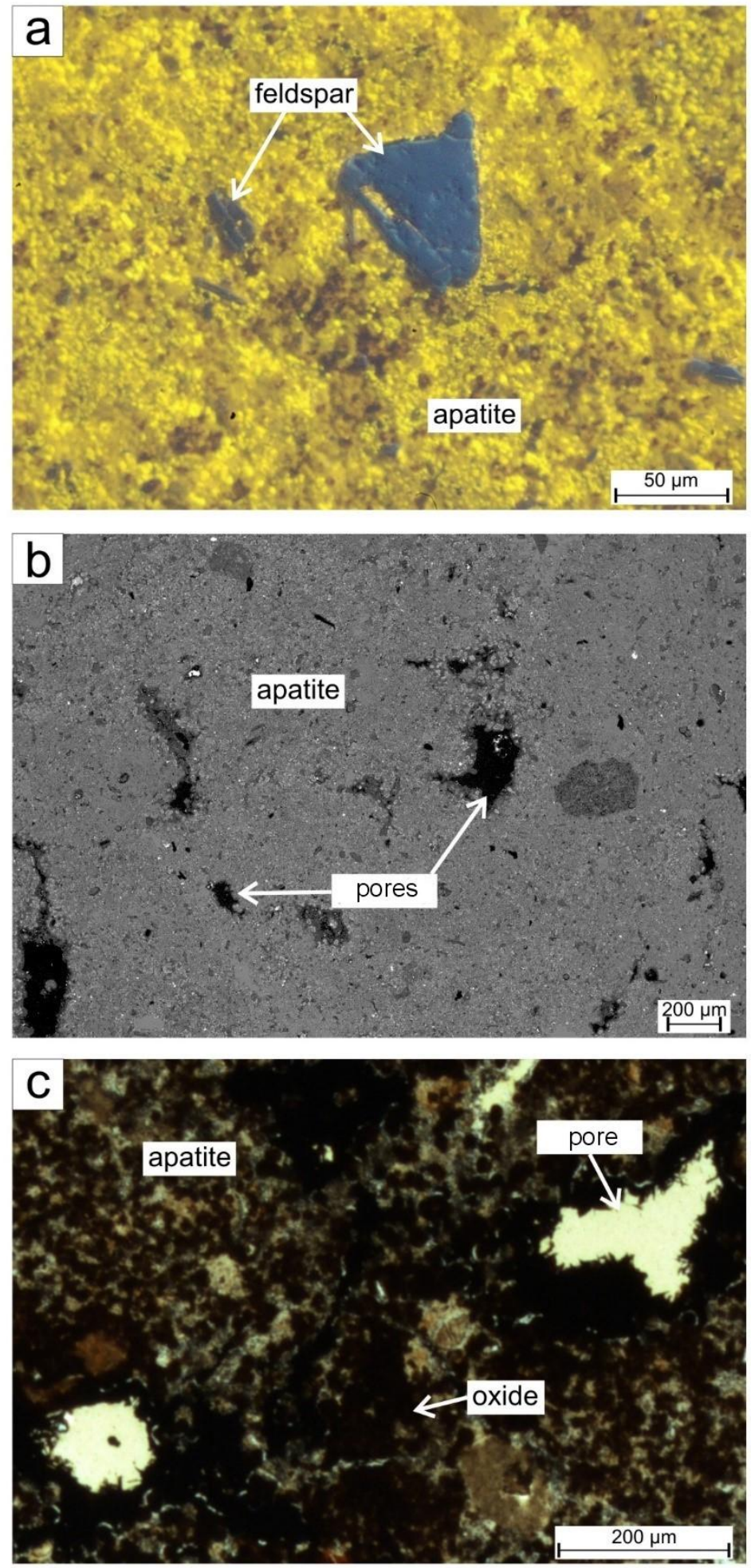
721
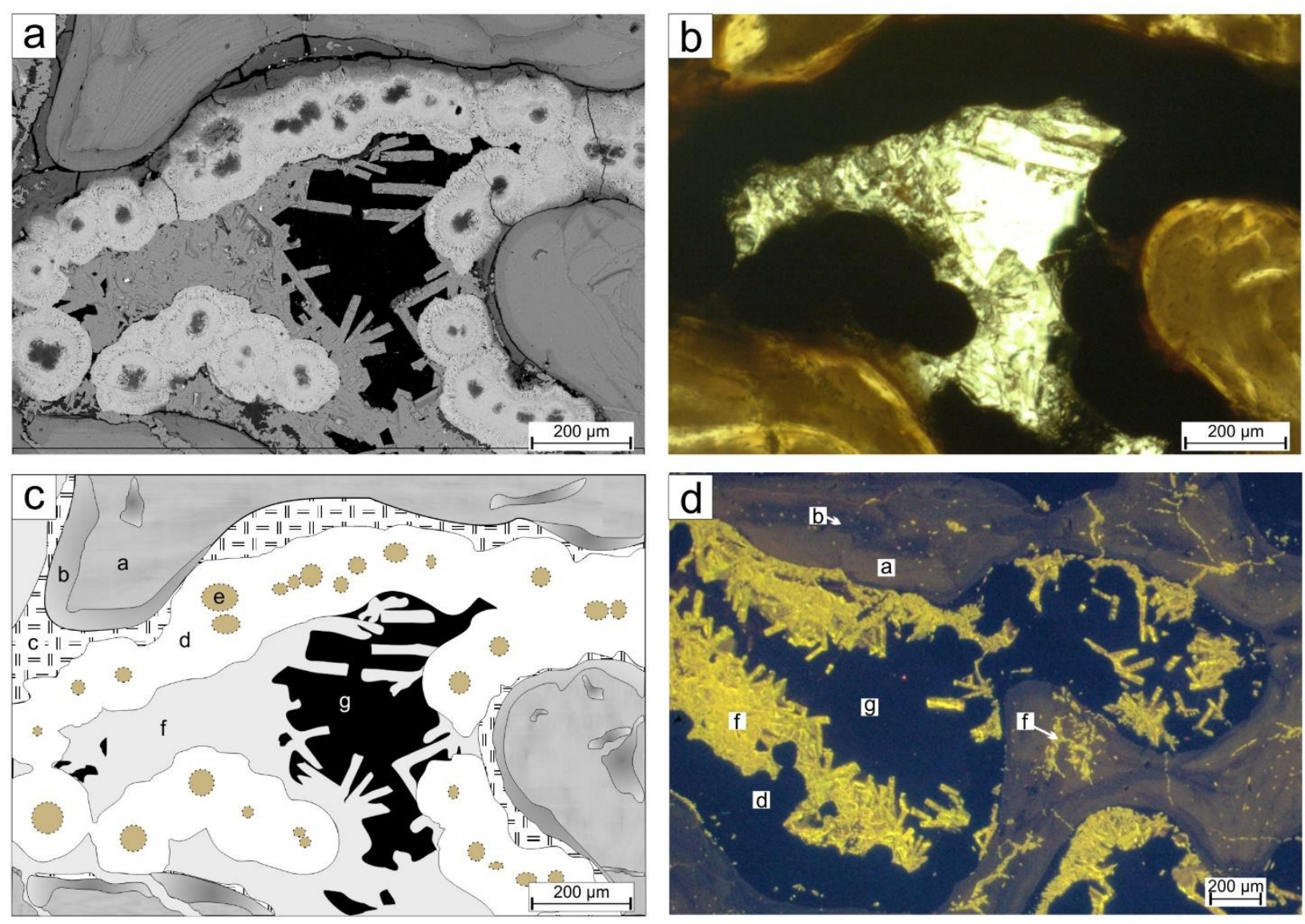

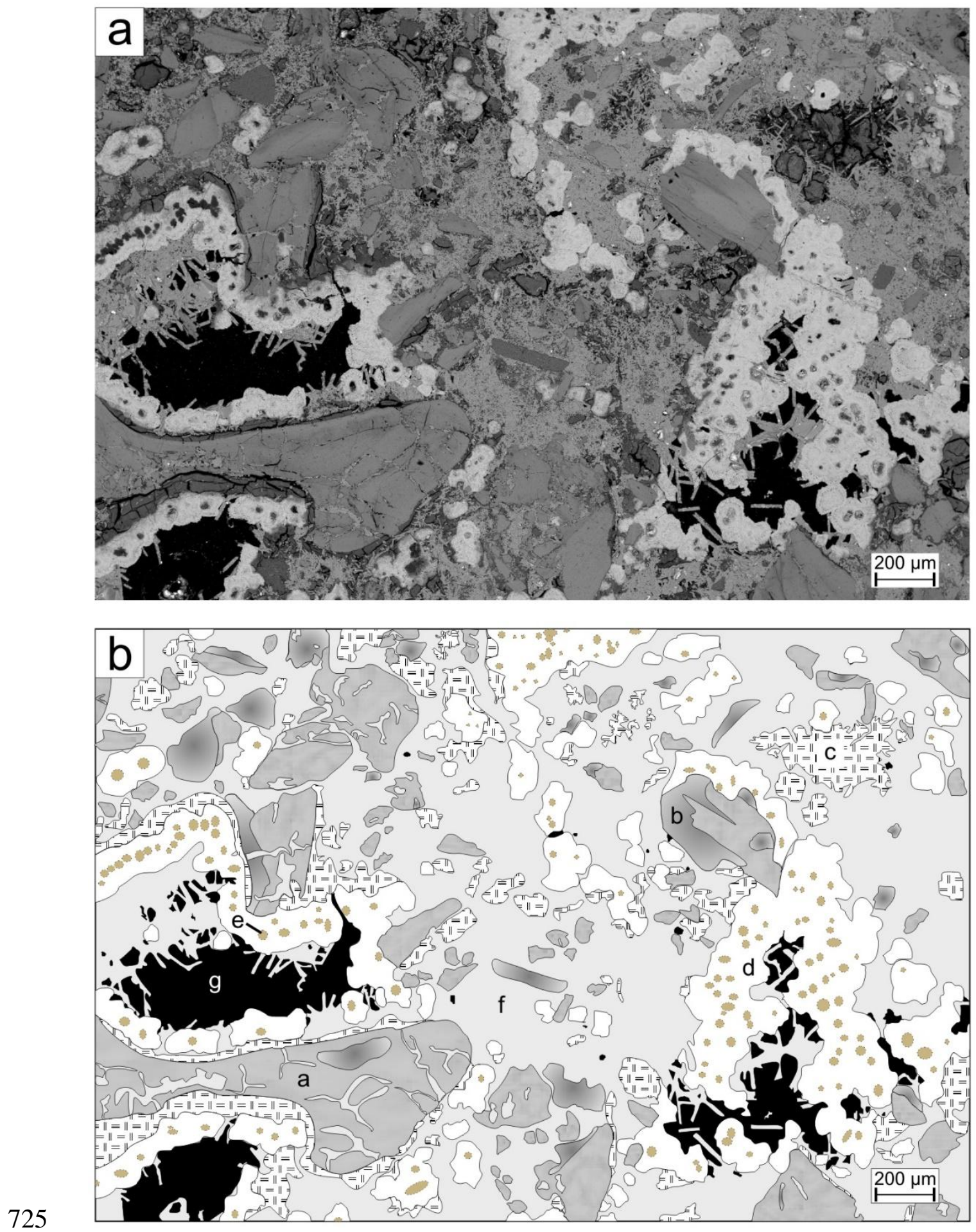
Figure 8

727

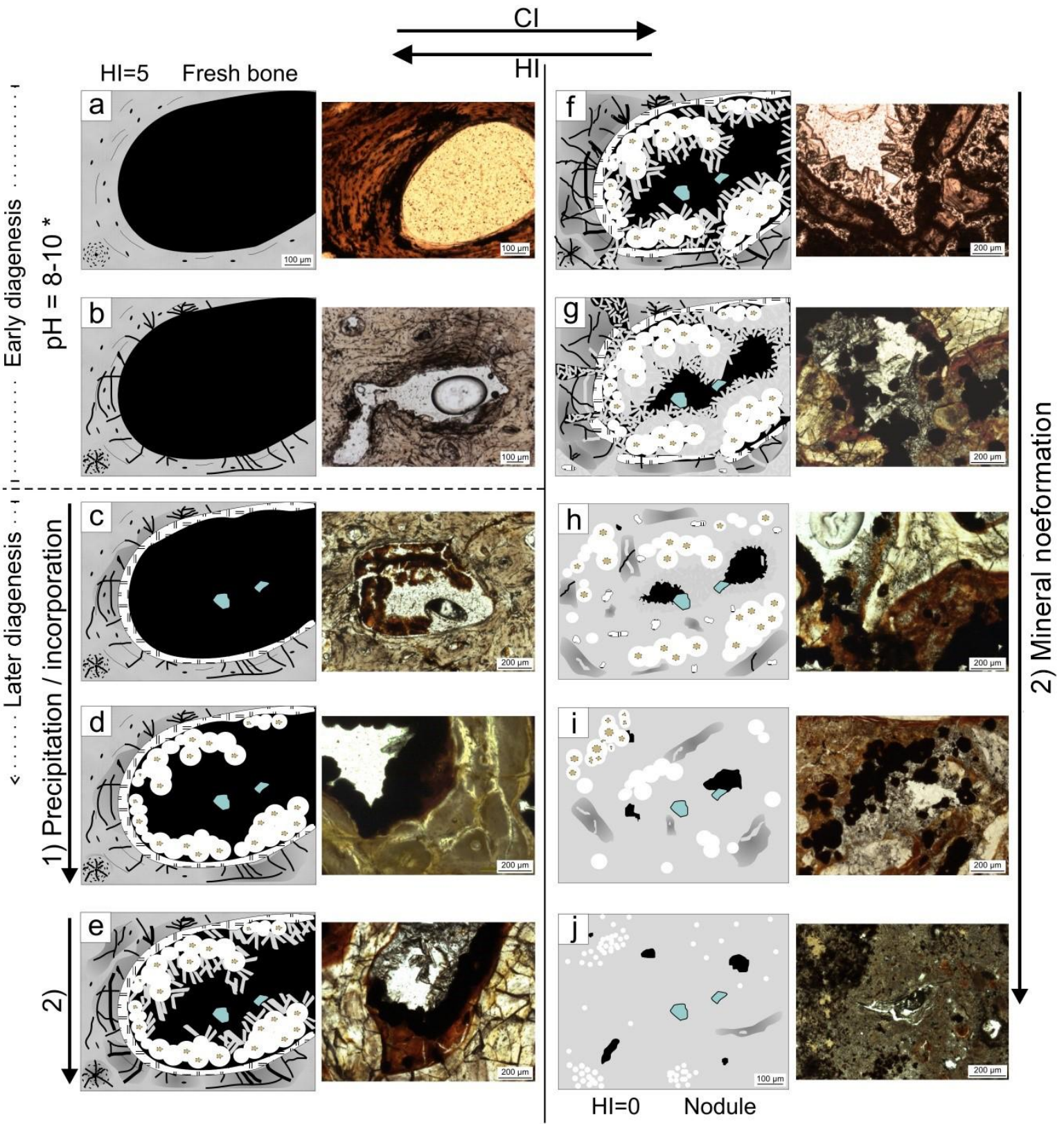

